$12-1992$

\title{
Life Histories in an Epifaunal Community: Coupling of Adult and Larval Processes
}

Brian L. Bingham

Western Washington University, brian.bingham@wwu.edu

Follow this and additional works at: https://cedar.wwu.edu/esci_facpubs

Part of the Environmental Sciences Commons

\section{Recommended Citation}

Bingham, Brian L., "Life Histories in an Epifaunal Community: Coupling of Adult and Larval Processes" (1992). Environmental Sciences Faculty and Staff Publications. 40.

https://cedar.wwu.edu/esci_facpubs/40 


\section{WILEY}

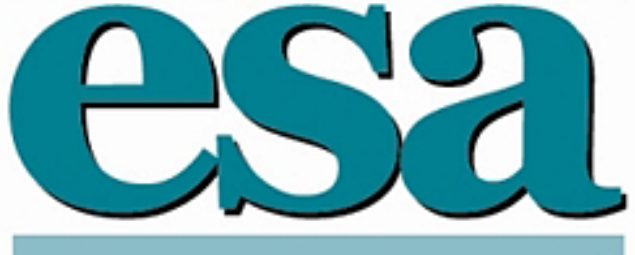

Life Histories in an Epifaunal Community: Coupling of Adult and Larval Processes Author(s): Brian L. Bingham

Source: Ecology, Vol. 73, No. 6 (Dec., 1992), pp. 2244-2259

Published by: Wiley on behalf of the Ecological Society of America

Stable URL: http://www.jstor.org/stable/1941472

Accessed: 18-04-2017 15:26 UTC

\section{REFERENCES}

Linked references are available on JSTOR for this article: http://www.jstor.org/stable/1941472?seq=1\&cid=pdf-reference\#references_tab_contents You may need to $\log$ in to JSTOR to access the linked references.

JSTOR is a not-for-profit service that helps scholars, researchers, and students discover, use, and build upon a wide range of content in a trusted digital archive. We use information technology and tools to increase productivity and facilitate new forms of scholarship. For more information about JSTOR, please contact support@jstor.org.

Your use of the JSTOR archive indicates your acceptance of the Terms \& Conditions of Use, available at http://about.jstor.org/terms

Wiley, Ecological Society of America are collaborating with JSTOR to digitize, preserve and extend access to Ecology 


\title{
LIFE HISTORIES IN AN EPIFAUNAL COMMUNITY: COUPLING OF ADULT AND LARVAL PROCESSES ${ }^{1}$
}

\author{
BRIAN L. BINGHAM ${ }^{2}$ \\ Harbor Branch Oceanographic Institution, 5600 Old Dixie Highway, \\ Fort Pierce, Florida 34946 USA
}

\begin{abstract}
Marine invertebrates growing epifaunally on red mangrove (Rhizophora mangle) prop roots in the Indian River, Florida, USA, were studied in a small mangrove island (Jim Island) through which a number of channels had been cut. Roots hanging down into the water supported diverse epifaunal communities including sponges, oysters, barnacles, bryozoans, and ascidians. To determine what factors control species' population dynamics and contribute to the high degree of spatial heterogeneity characteristic of communities in this unique habitat, two hypotheses were tested: (1) Distributions of species on the roots are controlled by differential growth and mortality due to physical features; and (2) Recruitment, as influenced by larval supply, structures the community.

Four channels of the island were chosen for comparison and experimentation. Distributions and abundances of epifauna in the channels were determined and physical parameters (i.e., temperature, $\mathrm{pH}$, salinity, flow, turbidity) were measured over a 13-mo period. Adult and early juvenile organisms were transplanted among channels and growth and survival were monitored. Patterns of water flow in the island were studied, and plankton samples were taken to determine how larval supply varied among channels in different parts of the island. General patterns of recruitment were measured for 9 mo and patterns were compared to adult distributions.

Epifaunal cover differed among the study channels, with dramatic differences in abundance and species diversity. Except for flow, physical factors did not differ significantly among channels. Flow rate, per se, was not responsible for disjunct distributions since neither adult nor juvenile survival (processes expected to be most affected by flow) differed among channels. Plankton samples and recruitment measurements revealed that the importance of larval supply depended on the life history of the individual species. Those producing short-lived lecithotrophic larvae showed patchy distributions that were strongly affected by the location of source populations and prevailing patterns of water flow. Species with long-lived planktotrophic larvae were more evenly distributed and post-settlement processes played a more important role in their population dynamics.

On large temporal or spatial scales, the effects of physical factors on juvenile and adult organisms are probably quite important in controlling epifaunal distributions. However, in this study, the distributions of organisms on Rhizophora mangle root within Jim Island were best explained by differential larval input, with larval life history determining the strength of coupling between adult populations, larval supply, and patterns of recruitment.

Key words: coupling of recruitment and adult distribution; epifauna; Indian River, Florida; larvae; larval dispersal; larval supply; life history; mangroves; recruitment; spatial heterogeneity and larval lifespan.
\end{abstract}

\section{INTRODUCTION}

In many tropical and subtropical coastal regions, mangrove trees (particularly in the genus Rhizophora) play an important role in the ecology of benthic marine invertebrates. Growing at the water's edge, these trees sprout aerial prop roots from the trunk and lower branches of the canopy. The roots, lengthening $\approx 3$ $\mathrm{mm} / \mathrm{d}$ (Gill and Tomlinson 1969), descend into the water where they may eventually reach the bottom and

\footnotetext{
'Manuscript received 19 July 1991; revised 16 January 1992; accepted 28 January 1992.

Present address: Shannon Point Marine Center, 1900 Shannon Point Road, Anacortes, Washington 98221-4042 USA.
}

take root. In many areas, substratum surrounding the mangrove fringe is loose or muddy bottom, and submerged roots are the only available hard surfaces for attachment and growth of sessile invertebrates (e.g., sponges, cnidarians, polychaetes, bivalves, barnacles, bryozoans, and ascidians). As a result, submerged $R h i$ zophora roots may support abundant and diverse epifaunal communities.

Early workers (e.g., Stephenson et al. 1931, Macnae and Kalk 1962, Macnae 1963, Rützler 1969) produced extensive lists of mangrove root associates or examined physical factors and correlated these with species diversity or biomass (Davis 1940, Davis and Williams 1950, Walsh 1967, Kolehmainen 1972, Kolehmainen et al. 1974, Yoshioka 1975, Frith et al. 1976). In many 


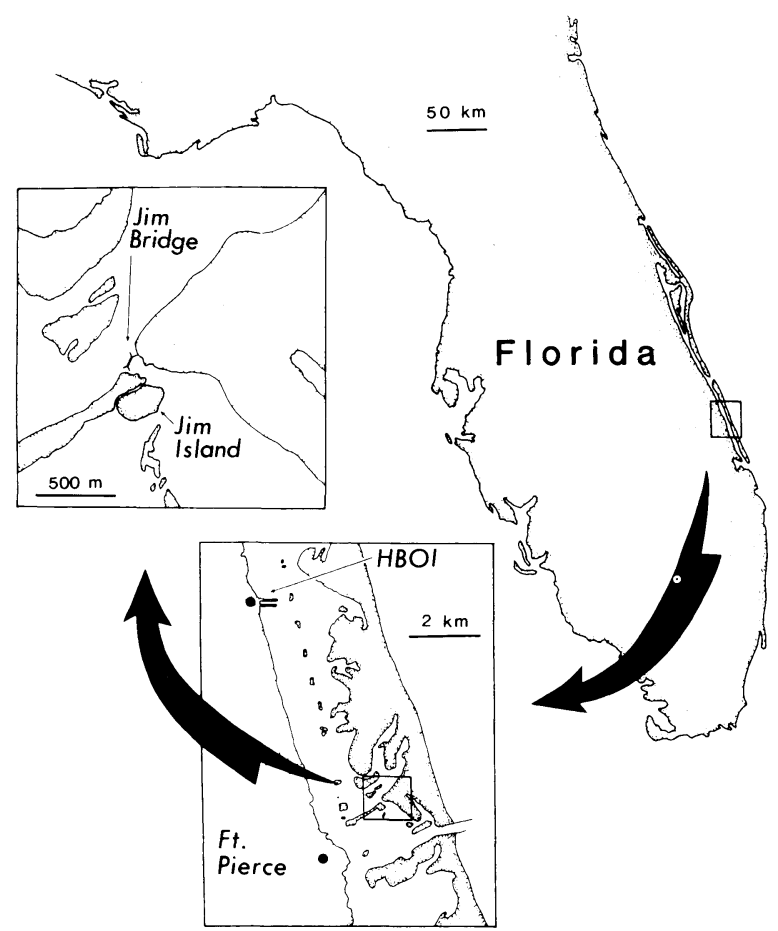

FIG. 1. Location of the study site in the Indian River Lagoon, Florida. HBOI $=$ Harbor Branch Oceanographic Institution.

of these studies, it was noted that species' distributions were very patchy (Davis 1940, Bacon 1970, Kolehmainen 1972, Kolehmainen et al. 1974, Yoshioka 1975). Generally, physical factors such as temperature (Kolehmainen et al. 1974), salinity (Walsh 1967, Bacon 1970, Ellison and Farnsworth, in press), dissolved oxygen (Davis 1940, Walsh 1967), pH (Davis 1940), turbidity (Kuenzler 1974), wave exposure (Kolehmainen 1972, Yoshioka 1975, Ellison and Farnsworth, in press), and flow (Rützler 1969, Kuenzler 1974, Yoshioka 1975) have been invoked to explain heterogenous distributions. However, significant variation in these factors probably occurs primarily on scales where adverse conditions or major disturbances (e.g., extremely heavy rains drastically reduce salinity; Goodbody 1961, Morgan 1977) impact an entire area. It is therefore uncertain whether they can produce the smaller-scale variability characteristic of these communities.

Sutherland (1980) hypothesized that the spatial heterogeneity present in a Venezuelan mangrove community resulted from differential larval recruitment. This suggestion is supported by plankton studies revealing considerable spatial variability in larval abundances in other mangrove habitats despite fairly constant environmental features (Davis and Williams 1950, Teixeira and Kutner 1962, Teixeira et al. 1965). At present, however, there is little experimental information linking adult distributional variability to larval supply, and it is unclear whether physical factors, re- cruitment processes, or some combination of both structure these communities. In south Florida there exists a unique mangrove habitat in which these questions could be addressed experimentally.

\section{Study site}

Jim Island is a small $(300 \times 200 \mathrm{~m})$ island in the Indian River lagoon on the east coast of Florida $\approx 7$ $\mathrm{km}$ south of the Harbor Branch Oceanographic Institution $\left(27^{\circ} 32^{\prime} \mathrm{N}, 80^{\circ} 21^{\prime} \mathrm{W}\right.$; Fig. 1). The island, composed largely of mangrove trees including the red mangrove Rhizophora mangle, is separated from a larger island on the north and west by a shallow channel (depth: $\approx 90 \mathrm{~cm}$ ), and is bordered on the south by seagrass beds and on the east by a deep navigation channel (Fig. 2).

In 1965 channels were dug throughout Jim Island to improve drainage and inhibit mosquito breeding (mid-channel depths from 39 to $94 \mathrm{~cm}$ at mean lower low water, MLLW). The channels are flushed by semidiurnal tidal flow through Fort Pierce Inlet, $2 \mathrm{~km}$ to the southeast. Prop roots of $R$. mangle lining the channels hang down into the water and support diverse epifaunal assemblages. Oysters (Crassostrea virginica) and barnacles (Balanus eburneus, B. amphitrite) predominate on high intertidal portions of the roots. Low intertidal and subtidal root surfaces are dominated by colonial ascidians and bryozoans. Due to the nature of flow in and around the island, channels in various portions of the island receive water flow from dissimilar areas and habitats. Qualitative observations revealed significant variability in root cover among channels; roots in some, particularly those in the southern part of the island, were nearly bare, while those in others

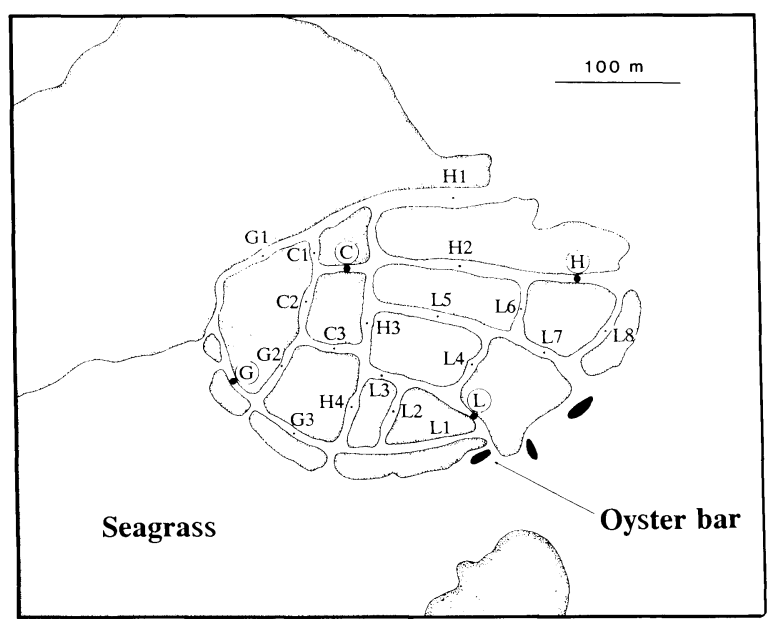

FIG. 2. Seagrass bed and local topography that influence water flow through Jim Island (Indian River, Florida). Study channels are indicated by the circled letters; $G=$ Grassbed channel, $\mathrm{C}=$ Central channel, $\mathrm{L}=$ Low-flow channel, $\mathrm{H}=$ High-flow channel. Remaining channels are referenced for recruitment data and are labelled to permit grouping with the study channels (see text and the Appendix). 
TABLE 1. Epifaunal species found in surveys of Rhizophora mangle prop roots in Jim Island (Indian River, Florida, USA) study channels $(\mathrm{G}=$ Grassbed channel, $\mathrm{C}=$ Central channel, $\mathrm{L}=$ Low-flow channel, $\mathrm{H}=$ High-flow channel). $+=$ present; $-=$ absent.

\begin{tabular}{|c|c|c|c|c|c|}
\hline \multirow[b]{2}{*}{ Phylum } & \multirow[b]{2}{*}{ Species } & \multicolumn{4}{|c|}{ Channel } \\
\hline & & $\mathrm{G}$ & $\mathrm{C}$ & $\mathrm{L}$ & $\mathrm{H}$ \\
\hline Porifera & $\begin{array}{l}\text { Hymeniacidon heliophila } \\
\text { Halichondria melanadocia } \\
\text { sponge sp. } 1\end{array}$ & $\begin{array}{l}+ \\
+ \\
-\end{array}$ & $\begin{array}{l}+ \\
- \\
-\end{array}$ & $\begin{array}{l}+ \\
+ \\
-\end{array}$ & $\begin{array}{l}+ \\
- \\
+\end{array}$ \\
\hline Mollusca & Crassostrea virginica & + & + & + & + \\
\hline Arthropoda & $\begin{array}{l}\text { Balanus amphitrite } \\
\text { Balanus eburneus }\end{array}$ & $\begin{array}{l}+ \\
+\end{array}$ & $\begin{array}{l}+ \\
+\end{array}$ & $\begin{array}{l}+ \\
+\end{array}$ & $\begin{array}{l}+ \\
+\end{array}$ \\
\hline Bryozoa & $\begin{array}{l}\text { Bugula neritina } \\
\text { Bugula stolonifera } \\
\text { Zoobotryon verticillatum }\end{array}$ & $\begin{array}{l}+ \\
- \\
+\end{array}$ & $\begin{array}{l}+ \\
+ \\
+\end{array}$ & $\begin{array}{l}+ \\
- \\
+\end{array}$ & $\begin{array}{l}+ \\
- \\
+\end{array}$ \\
\hline Chordata & $\begin{array}{l}\text { Ascidia nigra } \\
\text { Botryllus planus } \\
\text { Clavelina oblonga } \\
\text { Didemnum sp. } \\
\text { Didemnum candidum } \\
\text { Didemnum psammathodes } \\
\text { Diplosoma glandulosum } \\
\text { Ecteinascidia turbinata } \\
\text { Eudistoma capsulatum } \\
\text { Eudistoma hepaticum } \\
\text { Eudistoma olivaceum } \\
\text { Perophora viridis } \\
\text { Polyclinum constellatum } \\
\text { Styla plicata } \\
\text { Symplegma rubra } \\
\text { Symplegma viride }\end{array}$ & $\begin{array}{l}- \\
- \\
- \\
- \\
- \\
+ \\
+ \\
- \\
- \\
- \\
+ \\
- \\
+ \\
- \\
- \\
-\end{array}$ & $\begin{array}{l}+ \\
+ \\
- \\
+ \\
+ \\
+ \\
+ \\
- \\
- \\
- \\
+ \\
+ \\
+ \\
+ \\
+ \\
-\end{array}$ & $\begin{array}{l}- \\
+ \\
- \\
- \\
+ \\
- \\
- \\
+ \\
- \\
- \\
+ \\
- \\
- \\
- \\
- \\
-\end{array}$ & $\begin{array}{l}- \\
+ \\
+ \\
+ \\
+ \\
- \\
+ \\
+ \\
+ \\
+ \\
+ \\
+ \\
+ \\
+ \\
+ \\
+\end{array}$ \\
\hline $\begin{array}{l}\text { Total species present } \\
\text { Unique species }\end{array}$ & & $\begin{array}{r}11 \\
0\end{array}$ & $\begin{array}{r}18 \\
3\end{array}$ & $\begin{array}{r}11 \\
0\end{array}$ & $\begin{array}{r}20 \\
5\end{array}$ \\
\hline
\end{tabular}

harbored abundant and diverse communities of sessile organisms.

\section{Hypotheses}

The obvious heterogeneity of epifaunal populations within Jim Island and the discrete subunits (i.e., channels) available for experimentation permitted a study of the factors controlling epifaunal distribution. The study was framed around two alternative hypotheses, each associated with testable predictions:

Hypothesis 1: Disjunct epifaunal distributions result from differential growth or mortality due to variability in physical features of the channels.

Predictions: Epifaunal abundance and diversity will be lower in channels that experience more stressful physical features (e.g., extreme water flow, temperature, turbidity, etc.) due to greater mortality of juvenile or adult organisms.

Hypothesis 2: Import of larvae into the habitat controls distributions of epifaunal species. Differential distributions result from variability in recruitment as influenced by larval life-history characteristics.

Predictions: Larval recruitment will differ among channels and will reflect adult distributions. Patchiness will be correlated with length of larval life; recruitment of species with short-lived lecithotrophic (non-feeding) larvae will reflect proximity to source populations and prevailing patterns of water flow, while species that produce long-lived planktotrophic (feeding) larvae will recruit more homogeneously as mixing of water masses and other time-related processes decouple adult and larval populations.

\section{Materials AND Methods \\ Selection of channels for study}

To test the proposed hypotheses, four Jim Island channels were chosen for detailed comparison. Three criteria were used in choosing channels: (1) level of epifaunal coverage (based on qualitative root surveys), (2) location (channels in different areas of the island might receive different larval inputs), and (3) water flow rate (which should correlate with other important physical features). The channels selected (Grassbed, Central, Low-flow and High-flow channels; Fig. 2) approximated four "corners" of the island where root communities were qualitatively different (Table 1) and where preliminary observations had revealed differences in flow rate (Bingham 1990).

To determine if root epifauna differed quantitatively among study channels, I examined 10 roots in each. A 50-m line, marked at 1-m intervals, was placed down the center of the channel, and at 10 randomly chosen 
positions the nearest mangrove root extending into the water was examined. A $40 \times 20 \mathrm{~cm}$ acetate sheet with 200 random points was wrapped around the root from the high-water level, where sessile invertebrates first appeared, to $40 \mathrm{~cm}$ down the root, and the taxon immediately beneath each point was identified. As no root was fully $20 \mathrm{~cm}$ in circumference, only a fraction of the points was counted for any sample, and values were converted to percentages. Data were arcsine-transformed and abundances of the most common species were compared with one-way ANOVA. A posteriori pairwise comparisons were made with Student-Newman-Keuls (SNK) tests (Zar 1984).

\section{Physical features of the channels}

The physical environments of the channels were characterized to provide a basis for testing the hypothesis that low epifaunal diversity and abundance in some channels resulted from harsh physical features there. Temperature, $\mathrm{pH}$, dissolved oxygen, salinity, flow rate, and turbidity (all features that have been hypothesized to structure other mangrove epifaunal communities) were measured in the study channels at 1to 4-wk intervals between January 1988 and February 1989 (23 observations). Temperature and $\mathrm{pH}$ were measured with a Markson 6102 Digital Multimeter, dissolved oxygen with a YSI 57 Oxygen Meter, and salinity with a refractometer. Measurements were made in the centers of the channels 15 to $20 \mathrm{~cm}$ below the surface. Flow rate was estimated by measuring the time required for a drogue, weighted to float just below the surface, to move to the end of a 5-m tether. Results were analyzed with Kruskal-Wallis tests and critical $z$ values were calculated to make simultaneous comparisons among channels (Gibbons 1976).

Total water movement, integrated over several days, was examined with slowly dissolving clod cards (Doty $1971)$ made of hemispherical pieces of white carpenter's chalk $(5.7 \mathrm{~cm}$ diameter) attached with silicone adhesive to 9 -cm square pieces of Plexiglas. Three preweighed clod cards were placed on a wooden frame in the centers of the channels. After $96 \mathrm{~h}$ they were recovered, air-dried at $25^{\circ} \mathrm{C}$ for $72 \mathrm{~h}$, and reweighed. Dissolution rates were compared by one-way ANOVA, and pairwise comparisons of means were made with SNK tests.

Water turbidity was determined by measuring light intensity at the water's surface and 10 to $50 \mathrm{~cm}$ underwater (depth depending on tidal height) with a LICOR cosine Quantum Light Sensor attached to a LICOR 1000 Data Logger. An extinction coefficient $(k)$ was calculated according to the formula given by Parsons et al. (1984):

$$
k=\frac{\ln I_{0}-\ln I_{d}}{d}
$$

where $d=$ depth in metres, $I_{0}=$ light intensity at the surface and $I_{d}=$ light intensity at depth $d$. High values of $k$ indicate greater light attenuation due to turbidity. One-factor ANOVA was used to examine data following $\log$ transformation to homogenize variances. Pairwise comparisons between sites were made by Spjøtvoll and Stoline $T^{\prime}$ tests. This modification of Tukey's HSD was necessary due to unequal numbers of observations (Kirk 1982).

\section{Transplant survival}

It was predicted that, if adverse physical conditions were controlling distributions, growth and survival of epifaunal species would be lowest in channels with extreme conditions. This prediction was tested with transplants of three species that were heterogeneously distributed among the study channels (Table 1, Fig. 3). Small pieces of two colonial ascidian species, Botryllus planus and Didemnum psammathodes, were fastened to $7-\mathrm{cm}$ square Plexiglas plates with a rubber band. The plates were then attached to a polyvinyl chloride plastic frame hanging from a dock near Jim Island. After $5 \mathrm{~d}$ the plates were retrieved and examined. Those with firmly attached, actively growing ascidians were bolted to eight wooden stakes placed at 3-m intervals down the centers of each of the study channels. Survival and colony growth were recorded at 2- to 4-d intervals. After $19 \mathrm{~d}$ the numbers of surviving colonies were compared by contingency table analysis with $G$ statistics for goodness of fit; colony sizes were compared with $F$ tests.

The bryozoan Zoobotryon verticillatum was transplanted into the study channels by attaching small clumps of the filamentous colonies with rubber bands directly to $15 \times 15 \mathrm{~cm}$ unglazed ceramic tiles in racks at the center of the channels (three replicate plates per channel). Condition of the transplants was assessed at 2- to 5-d intervals for $25 \mathrm{~d}$.

Because early juveniles are often particularly vulnerable to mortality, I also tested whether early postsettlement mortality contributed to uneven species' distributions. Twelve unglazed ceramic tiles were placed in an unstudied channel of the island and allowed to accumulate recruits for $5 \mathrm{~d}$. Each recruiting species was assigned a symbol (e.g., circle, square), which was drawn around individual recruits with a pencil. Three randomly chosen, marked tiles were suspended from racks placed in the middle of the study channels. Survival was monitored at 2- to 5-d intervals (growth was used as an indicator of $H y$ droides sp. survival).

Since tiles held unequal numbers of recruits and some species occurred in low numbers, statistical comparisons of survivorship were inappropriate for all species except barnacles, which were analyzed by ANOVA and SNK tests. Data for all other species were pooled to determine total species mortality within each channel.

To determine if low juvenile growth might eventually contribute to mortality unseen in the short period of this experiment, I also measured growth of the $\mathrm{Bal}$ anus eburneus recruits. At the conclusion of the ex- 

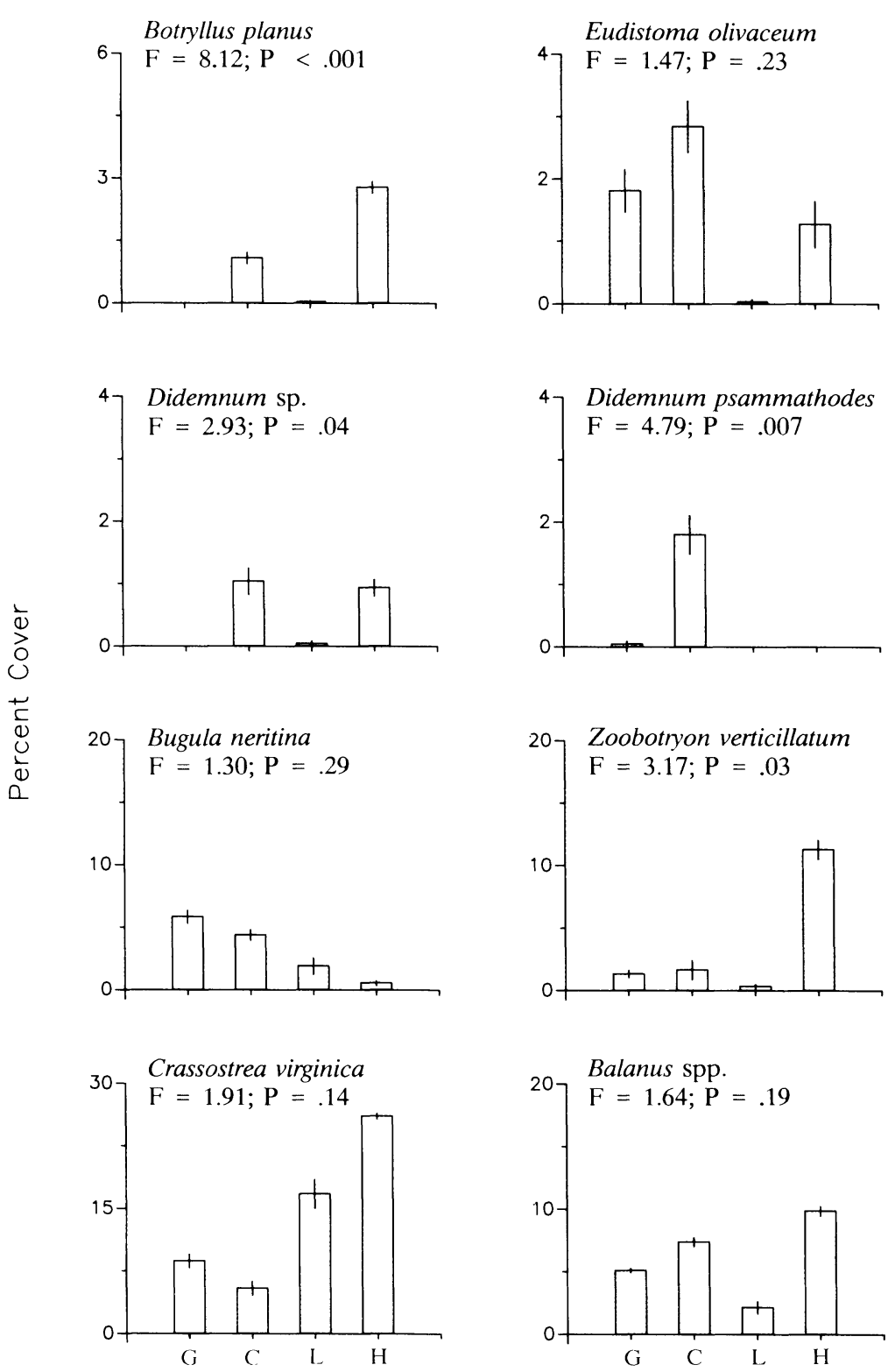

\section{Channel}

FIG. 3. Epifaunal abundances on Rhizophora mangle roots in Grassbed (G), Central (C), Low-flow (L), and High-flow (H) channels in Jim Island, Indian River, Florida. Error bars drawn on histogram bars show \pm 1 SE.

periment, tiles were recovered and rostral-carinal lengths of 30 barnacles from each channel were measured. Results were compared by one-way ANOVA and SNK pairwise comparisons.

\section{Water flow}

To test the possibility that differential larval supply controlled species distributions, it was first necessary to determine how water circulated through Jim Island and from where larvae would be transported into the study channels. Large-scale flow was visualized by releasing drogues around the island during a number of incoming and outgoing tides and tracking their movements.

Patterns of larval dispersal within Jim Island were modeled with polystyrene test tubes $(6 \mathrm{~mL})$ weighted to float upright at the water's surface. Fifty tubes (corked, sealed with paraffin, and color-coded) were released at the western ends of Central, Low-flow, and High-flow channels. Their positions $4,24,48$, and $72 \mathrm{~h}$ after release were determined by searching all channels and noting tube locations on a map. Distances traveled were estimated by measuring the shortest dispersal path of each tube from its release point. Dispersal distances 
were compared by one-way ANOVA of log-transformed data.

\section{Planktonic larval abundance}

Plankton samples were taken to determine if there were differences in larval abundances in the study channels. Three replicate 38 -L samples were taken at 3-m intervals down the center of each channel by scooping up surface water with a bucket. Samples were filtered through $63-\mu \mathrm{m}$ Nitex netting, preserved in $5 \%$ formalin, and counted. As species identifications were impractical in most cases, larvae were classified by larval form (e.g., polychaete setigers, barnacle nauplii, etc.). Samples were collected in March and April 1989. Data were log-transformed and analyzed in a mixedmodel ANOVA (Sokal and Rohlf 1981) with main effects of date and channel. Because colonial ascidian tadpoles were present on only one date, those data were analyzed by simple one-way ANOVA. To decrease the probability of Type I error by adopting a table-wide $\alpha$ $=.05$, the $P$ value for declaring significance was determined with a sequential Bonferroni technique (Rice 1989). Significant channel effects were further analyzed with SNK tests.

\section{Recruitment}

To assess spatial recruitment patterns and determine how they related to adult distributions, a single unglazed ceramic tile $(15 \times 15 \mathrm{~cm})$ was hung from a Rhizophora root near the middle of the channels. Because mangrove trimming is prohibited in Florida, it was not possible to use roots for recruitment assays, and tiles served as a necessary alternative. The tiles hung by nylon monofilament line $10 \mathrm{~cm}$ below lowwater level. Eighteen separate sampling trials, with immersion times from 10 to $15 \mathrm{~d}$, were done between February and October 1987. At the end of each sampling period, new tiles were put in place and the old tiles were carefully examined for recruits. Although data were analyzed statistically only for the four primary study channels, recruitment in 18 additional channels was monitored to determine whether patterns were consistent throughout the island. Knowledge of flow rates (Bingham 1990) and channel positions was used to categorize each of the peripheral channels with one of the main study channels. This resulted in the identification of three additional "central-type" and "grassbed-type" channels, four additional "high-flowtype" channels, and eight additional "low-flow-type" channels (Fig. 2). It was predicted that recruitment would be similar within each of these categories.

Recruitment in Central, Grassbed, High-flow, and Low-flow channels was compared by randomized-block ANOVA, with sampling period as the blocking factor. Due to unequal sample sizes (some tiles were lost), a posteriori channel comparisons were made by Spjøtvoll and Stoline tests. Patterns were examined for the most common epifaunal species as well as two polychaete species (Spirorbis sp. and Hydroides sp.) and a slipper limpet (Crepidula convexa) that, though not common on the mangrove roots, appeared in large numbers on the tiles. Source populations of these species were mapped by examining the substratum along five transects (300-400 m long) parallel to the southern side of the island. At three equally spaced points a grab of seagrass was taken and the relative abundances of three seagrasses (Thalassia testudinum, Syringodium filliforme, and Halodule wrightii) and the numbers of polychaetes on three randomly selected blades of each species were determined. Values were converted to polychaetes per square centimetre for each seagrass species and data were totalled to yield a mean polychaete density for each sample point.

\section{RESULTS}

\section{Epifaunal root communities}

Examination of randomly chosen roots showed distinct differences among channels in both distributions and abundances of epifauna (Table 1, Fig. 3). Grassbed and Low-flow channels were dominated by oysters (Crassostrea virginica) and barnacles (Balanus spp.), with only a few other species present in low numbers. Large portions of many roots were bare, and unoccupied space in these channels exceeded that in the two northern channels $-62.7 \pm 19.1 \%$ in Grassbed and $60.2 \pm 15.1 \%$ in Low-flow compared to only $42.8 \pm$ $7.9 \%$ in Central and $24.3 \pm 4.3 \%$ in High-flow $(\bar{X} \pm$ $1 \mathrm{sD} ; F=2.79$, df $=3,36, P=.05$ ).

Epifaunal diversity was greatest in the High-flow channel ( 20 species) with one sponge and four ascidian species restricted to this channel (Table 1). Populations of barnacles and oysters were high but many other species were also common. The ascidians Botryllus planus and Didemnum sp. were significantly more abundant here than in Grassbed and Low-flow channels, and populations of the ctenostome bryozoan Zoobotryon verticillatum were larger here than in any other channel.

Central channel was similar to High-flow in having many species (18) and in having unique species (one bryozoan and two ascidians). As in the High-flow channel, Botryllus planus and Didemnum sp. were more common than in the two southern channels. A third ascidian, Didemnum psammathodes, was much more abundant here than anywhere else.

Three species common in the seagrass beds around Jim Island (the polychaetes Spirorbis sp. and Hydroides sp. and the slipper limpet Crepidula convexa) were also present on the mangrove roots, but due to their small size and low numbers they were ineffectively censused by the point-sampling method used. Individuals of all three species were present in all study channels, but no distributional patterns were obvious. 


\section{Physical parameters}

Kruskal-Wallis tests showed no consistent channel differences in dissolved oxygen $(H=0.71, \mathrm{df}=3, P$ $>.95)$, salinity $(H=2.828, \mathrm{df}=3, P>.50)$, temperature $(H=0.18, \mathrm{df}=3, P>.99)$, or $\mathrm{pH}(H=2.62$, $\mathrm{df}=3, P>.50)$. These physical features showed seasonal trends, but the differences in measurements at any sample date were very small, and no particularly extreme values were apparent in the channels (Table 2). Likewise, ANOVA showed no differences in turbidity levels ( $F=0.76$, df $=3,56, P=.52$ ) among channels. However, sediment loads were, on occasion, very heavy in the Low-flow channel, with maximum extinction coefficients twice those measured in any other channel.

Flow rate differed significantly among sites $(H=$ 29.80, $\mathrm{df}=3, P<.001$ ). Pairwise comparisons showed that flow was significantly higher in the High-flow channel and lower in the Low-flow channel (Fig. 4, Table 2). Flow data collected by measuring clod-card dissolution over $96 \mathrm{~h}$ verified the significant effect $(F$ $=25.06, \mathrm{df}=3,8, P<.001)$ and SNK tests revealed a similar pattern (i.e., High-flow $>$ Grassbed $=$ Central $>$ Low-flow; Fig. 4).

\section{Transplants}

Adult Didemnum psammathodes transplanted on plates suffered $50 \%$ mortality in the Central channel, $25 \%$ mortality in the Grassbed and Low-flow channels, and $0 \%$ mortality in the High-flow channel $(n=8$ for

TABLE 2. Measurements of physical parameters taken in Jim Island study channels (Indian River, Florida) between January 1988 and February 1989 (23 observations).

\begin{tabular}{|c|c|c|c|c|c|}
\hline Parameter & Channel & Mean & SD & Min & $\operatorname{Max}$ \\
\hline $\begin{array}{l}\text { Temperature } \\
\left({ }^{\circ} \mathrm{C}\right)\end{array}$ & $\begin{array}{l}\text { Grassbed } \\
\text { Central } \\
\text { Low-flow } \\
\text { High-flow }\end{array}$ & $\begin{array}{l}23.3 \\
23.1 \\
23.4 \\
23.5\end{array}$ & $\begin{array}{l}4.9 \\
4.9 \\
4.7 \\
4.9\end{array}$ & $\begin{array}{l}13.9 \\
14.4 \\
14.8 \\
14.3\end{array}$ & $\begin{array}{l}31.2 \\
30.5 \\
31.0 \\
32.0\end{array}$ \\
\hline $\mathrm{pH}$ & $\begin{array}{l}\text { Grassbed } \\
\text { Central } \\
\text { Low-flow } \\
\text { High-flow }\end{array}$ & $\begin{array}{l}6.4 \\
6.4 \\
6.4 \\
6.4\end{array}$ & $\begin{array}{l}0.1 \\
0.1 \\
0.1 \\
0.1\end{array}$ & $\begin{array}{l}6.2 \\
6.2 \\
6.2 \\
6.3\end{array}$ & $\begin{array}{l}6.6 \\
6.6 \\
6.7 \\
6.6\end{array}$ \\
\hline $\begin{array}{l}\text { Dissolved } \mathrm{O}_{2} \\
\quad(\mathrm{mg} / \mathrm{kg})\end{array}$ & $\begin{array}{l}\text { Grassbed } \\
\text { Central } \\
\text { Low-flow } \\
\text { High-flow }\end{array}$ & $\begin{array}{l}6.2 \\
6.0 \\
6.2 \\
6.3\end{array}$ & $\begin{array}{l}1.9 \\
1.7 \\
1.8 \\
1.5\end{array}$ & $\begin{array}{l}2.8 \\
2.7 \\
3.1 \\
3.5\end{array}$ & $\begin{array}{r}11.0 \\
9.8 \\
10.9 \\
9.6\end{array}$ \\
\hline $\begin{array}{l}\text { Salinity } \\
\qquad(\mathrm{mg} / \mathrm{kg})\end{array}$ & $\begin{array}{l}\text { Grassbed } \\
\text { Central } \\
\text { Low-flow } \\
\text { High-flow }\end{array}$ & $\begin{array}{l}35.3 \\
35.2 \\
35.9 \\
35.9\end{array}$ & $\begin{array}{l}1.8 \\
1.9 \\
1.6 \\
1.8\end{array}$ & $\begin{array}{l}31.0 \\
31.0 \\
32.0 \\
31.0\end{array}$ & $\begin{array}{l}37.0 \\
37.0 \\
38.0 \\
39.0\end{array}$ \\
\hline Flow $(\mathrm{cm} / \mathrm{s})$ & $\begin{array}{l}\text { Grassbed } \\
\text { Central } \\
\text { Low-flow } \\
\text { High-flow }\end{array}$ & $\begin{array}{r}8.7 \\
10.8 \\
4.4 \\
21.1\end{array}$ & $\begin{array}{r}6.1 \\
6.4 \\
4.9 \\
13.2\end{array}$ & $\begin{array}{l}0.0 \\
0.0 \\
0.0 \\
0.0\end{array}$ & $\begin{array}{l}25.4 \\
24.3 \\
16.7 \\
54.4\end{array}$ \\
\hline $\begin{array}{l}\text { Turbidity } \\
\text { (light extinc- } \\
\text { tion rate, } k \text { ) }\end{array}$ & $\begin{array}{l}\text { Grassbed } \\
\text { Central } \\
\text { Low-flow } \\
\text { High-flow }\end{array}$ & $\begin{array}{l}1.4 \\
2.1 \\
2.6 \\
1.5\end{array}$ & $\begin{array}{l}0.6 \\
1.7 \\
3.2 \\
1.1\end{array}$ & $\begin{array}{l}0.4 \\
0.4 \\
0.4 \\
0.3\end{array}$ & $\begin{array}{r}2.9 \\
6.3 \\
12.3 \\
4.4\end{array}$ \\
\hline
\end{tabular}

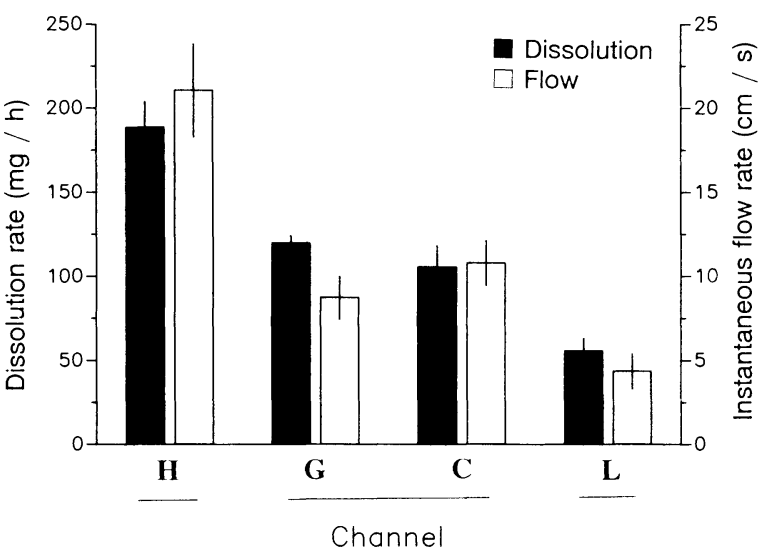

FIG. 4. Flow rate as measured with clod cards (cards bearing slowly dissolving carpenter's chalk) deployed for 96 h (ם) and with a subsurface floating drogue released in the centers of the channels $(\square)$. Error bars show +1 or \pm 1 SE. Lines beneath channel letters indicate measurements not significantly different by Student-Newman-Keuls pairwise comparisons.

each site), but the difference was nonsignificant ( $G=$ 1.66; $\mathrm{df}=3, P>$.75). There was no Botryllus planus mortality among transplants in Central, Low-flow, or High-flow channels. Three of eight colonies (37.5\%) died in the Grassbed channel, but this difference was again nonsignificant $(G=5.39 ; \mathrm{df}=3, P>.10)$. No transplanted Zoobotryon verticillatum colonies died during the experiment.

Didemnum psammathodes colony size at the end of the experiment did not differ among channels (Central $=9.0 \pm 8.29 \mathrm{~cm}^{2}$, High-flow $=11.33 \pm 8.74 \mathrm{~cm}^{2}$, Grassbed $=15.17 \pm 13.66 \mathrm{~cm}^{2}$, Low-flow $=21.67 \pm$ $\left.15.47 \mathrm{~cm}^{2} ; F=0.90, \mathrm{df}=3,15, P=.46\right)$. On the other hand, $B$. planus colony sizes differed (High-flow $=18.25$ $\pm 21.3 \mathrm{~cm}^{2}$, Grassbed $=35.5 \pm 16.3 \mathrm{~cm}^{2}$, Central $=$ $42.9 \pm 10.2 \mathrm{~cm}^{2}$, Low-flow $=43.8 \pm 8.2 \mathrm{~cm}^{2} ; F=$ 4.30; $\mathrm{df}=3,21, P=.016$ ), with colonies in the Highflow channel significantly smaller than those in the Low-flow channel (Spjøtvoll and Stoline's test, $\alpha=$ $.05)$.

Three ascidian species (Symplegma viride, Diplosoma glandulosum, and Botryllus planus) settled in sufficient numbers to examine early juvenile survival. There were no apparent differences in survival of any of these (though B. planus recruits were not placed in the High-flow channel), and growth was evident in all surviving colonies. All recruits survived in Grassbed and Central channels. Only two of $16 \mathrm{~S}$. viride colonies died (one each in Low-flow and High-flow channels). One $D$. glandulosum colony died in the High-flow channel $(n=19)$ and no B. planus colonies died $(n=$ 6).

Similarly low mortality was seen with recruits of the serpulid polychaete Hydroides sp.; only 2 of 65 individuals died (both in the Low-flow channel). The bar- 


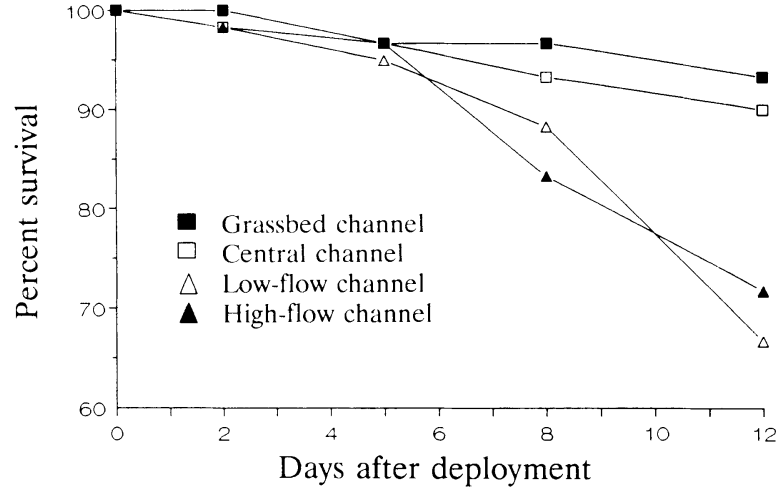

FIg. 5. Survival of early juvenile barnacles (Balanus spp.) transplanted into the study channels (Indian River, Florida). Data are the mean percentage of survival on three ceramic tiles. Tiles accumulated recruits for $5 \mathrm{~d}$ prior to transplant (Day 0 of deployment).

nacle Balanus eburneus was the only recruiting species showing survivorship differences among channels $(F=$ $10.49, \mathrm{df}=3,8, P=.004)$; survival was higher in Grassbed and Central channels than in Low-flow and High-flow channels (SNK test, $\alpha=.05$; Fig. 5). ANOVA and SNK tests revealed that, while barnacle survival was high in the Grassbed channel, individuals were significantly smaller there (Grassbed $=4.16 \pm$ $0.72 \mathrm{~mm} ;$ Low-flow $=4.97 \pm 1.04 \mathrm{~mm} ;$ Central $=5.33$ $\pm 0.76 \mathrm{~mm}$; High-flow $=5.41 \pm 1.21 \mathrm{~mm} ; \bar{X} \pm 1 \mathrm{sD}$; $F=10.68, \mathrm{df}=3,116, P<.001)$.

\section{Flow patterns}

Water flow through Jim Island was generally unidirectional (from southwest to northeast) despite reversing tidal flow in the Indian River. Most water exchange occurred through a few major channels with peripheral channels receiving little of the bulk flow (Fig. 6). The Grassbed and, to a lesser extent, the Central channel received water draining from extensive, shallow seagrass beds southwest of the island. High-flow was the main drainage channel for the island; much of the water from the seagrass beds and other channels eventually flowed out this channel into a deeper river channel east of the island. Flow in the Low-flow channel was very slow due to its orientation and an extensive oyster bar at its mouth that cut off water movement as tide level dropped. Occasionally, flow through the island reversed directions, and water from the river channel to the east flowed through the island and drained into the seagrass beds to the west.

There were large differences in dispersal of surfacefloating drift tubes released in the study channels. Drifters in the High-flow channel dispersed much more quickly than those in the Low-flow or Central channels (Fig. 7). Surprisingly, although flow was slowest in the Low-flow channel (Fig. 4), the tube dispersal rate was lowest in the Central channel. ANOVA revealed that these differences were significant $4 \mathrm{~h}(F=5.92$, df $=$ $2,71, P=.004), 24$ h $(F=10.9, \mathrm{df}=2,59, P<.001)$, and $48 \mathrm{~h}(F=3.34, \mathrm{df}=2,46, P=.04)$ after release. Because only one tube released in the High-flow channel remained in the island after $72 \mathrm{~h}$, it was not possible

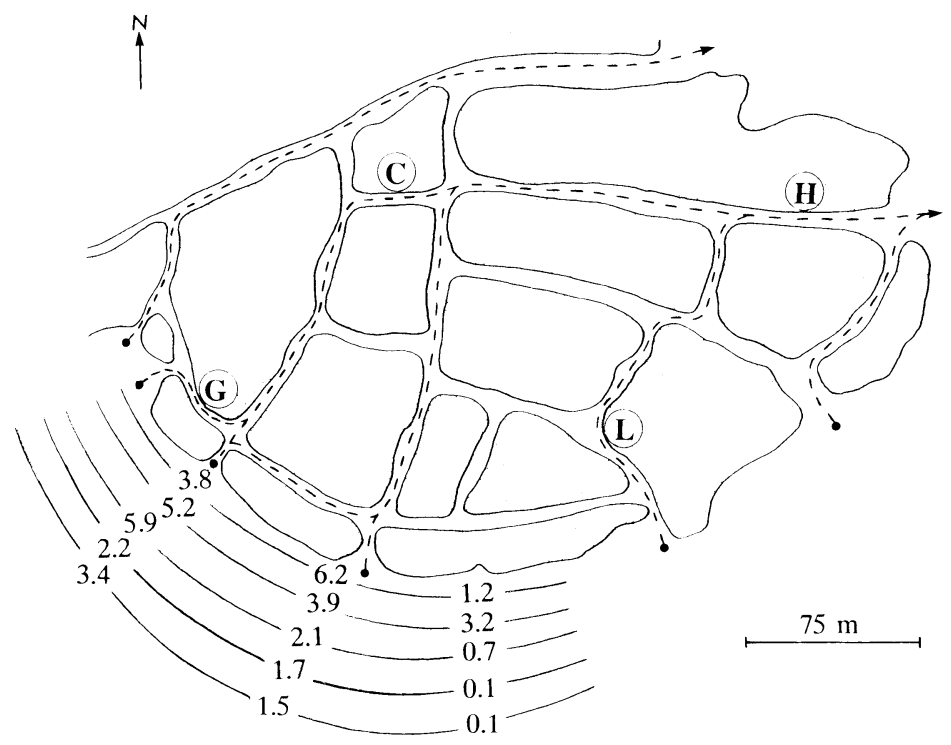

FIG. 6. Water flow through channels in Jim Island (Indian River, Florida) as indicated by subsurface floating drogues released at points indicated by black dots. Study channels are identified as in Table 5 footnote. Transect labels on the south side of the island are abundances of Spirorbis (numbers per square centimetre of seagrass blade) at three points along each transect. 


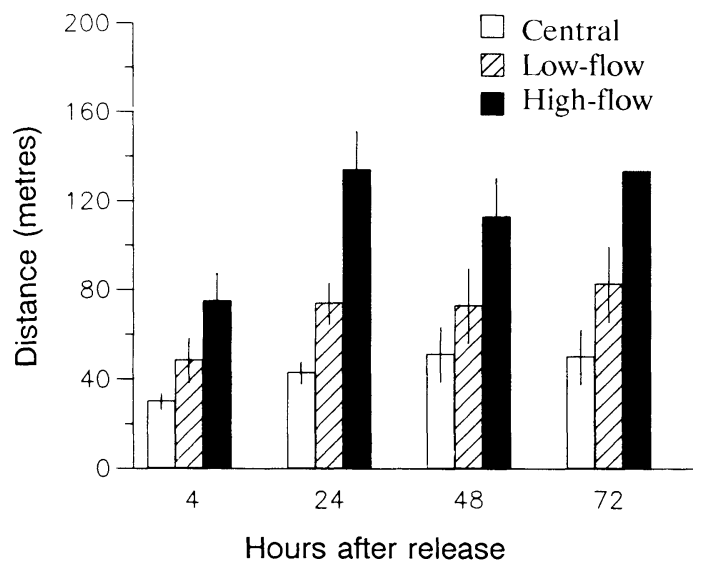

FIG. 7. Distances traveled by drift tubes released in the Central, Low-flow, and High-flow channels. Error bars show +1 or \pm 1 SE. No error is indicated on the bar for the Highflow channel on the 72-h sample because the measurement was based on a single drift tube (all other tubes having been flushed from the island).

to statistically compare distances in the 72-h sample, but the pattern appeared the same (Fig. 7).

\section{Plankton samples}

Spatial variability in larval supply was seen only with colonial ascidian tadpole larvae, which were nearly ten times more abundant in Central channel than in any other channel (Table 3).

\section{Recruitment}

Large numbers of organisms recruited to the tiles in Jim Island, and most species showed distinct temporal variability (Fig. 8). In addition, all species, except the oyster Crassostrea virginica, showed significant spatial variability (Table 4). Several different spatial patterns were evident in the data for the four study channels, and patterns were quite consistent within each channel "type" for the remaining 18 channels (Appendix).

Seagrass bed recruiters. - Spirorbis sp. and Crepidula convexa appeared in greatest numbers on tiles in the channels receiving water flowing from the seagrass bed to the south of the island. Both were more abundant in Seagrass and Central channels than in the eastern channels (i.e., Low-flow and High-flow), which received water flow from other sources. A similar trend appeared in the recruitment patterns of a second polychaete, Hydroides sp., though pairwise comparisons did not show this statistically (Tables 4 and 5). The Appendix reveals that recruitment of these species was generally high in grassbed-type and main drainage channels and low in low-flow-type channels.

Adults of these species occurred primarily in the seagrass bed to the south of the island. Populations of Spirorbis sp. were particularly abundant on Halodule wrightii blades near the mouth of the Seagrass channel (Fig. 6) and decreased along the transect toward the Low-flow channel. Hydroides sp. and C. convexa adults were also occasionally found on seagrass blades but were much more common on numerous mollusk shells scattered throughout the seagrass bed (see also Hoagland 1984).

Central channel recruiters. - Two bryozoans (Bugula neritina and $B$. stolonifera) and four colonial ascidians (Acidia nigra, Botryllus planus, Didemnum psammathodes, and Symplegma viride) all showed maximum recruitment in the Central channel and other central-type channels (Table 5, Appendix). Recruitment was also quite high in High-flow and many of the high-flow-type channels. No recruitment of these species was seen in many of the low-flow-type channels.

Mixed pattern recruiters. - Balanus spp. showed very heavy recruitment in Jim Island, with up to 1600 recruits per day on the 22 tiles (Fig. 8). The pattern of recruitment was unlike that seen for any other species (Tables 4 and 5). Numbers were highest in the Seagrass and High-flow channels (at the far upstream and downstream ends of Jim Island) and significantly lower in the Low-flow channel (although a number of low-flowtype channels showed very heavy recruitment; see the Appendix).

TABLE 3. Planktonic larval abundances in Grassbed (G), Central (C), Low-flow (L), and High-flow (H) channels of Jim Island. Indian River, Florida. Numbers are the total number of larvae collected in three 38-L water samples in each channel. $P$ values for mixed-model analysis of variance are given for the main effects (Date and Channel) and interaction $(\mathrm{D} \times \mathrm{C})$; statistically significant values are shown in bold type.

\begin{tabular}{|c|c|c|c|c|c|c|c|c|}
\hline \multirow[b]{2}{*}{ Species } & \multirow[b]{2}{*}{ Date } & \multicolumn{4}{|c|}{ Channel } & \multicolumn{3}{|c|}{ Model term } \\
\hline & & $\mathrm{G}$ & $\mathrm{C}$ & $\mathrm{L}$ & $\mathrm{H}$ & Date & Channel & $\mathrm{D} \times \mathrm{C}$ \\
\hline Polychaete setigers & $\begin{array}{l}\text { Mar } \\
\text { Apr }\end{array}$ & $\begin{array}{r}153 \\
50\end{array}$ & $\begin{array}{r}128 \\
51\end{array}$ & $\begin{array}{r}90 \\
111\end{array}$ & $\begin{array}{r}191 \\
79\end{array}$ & .002 & .804 & .102 \\
\hline Barnacle nauplii & $\begin{array}{l}\text { Mar } \\
\text { Apr }\end{array}$ & $\begin{array}{r}122 \\
60\end{array}$ & $\begin{array}{l}641 \\
119\end{array}$ & $\begin{array}{r}331 \\
86\end{array}$ & $\begin{array}{l}632 \\
175\end{array}$ & $\ll .001$ & .041 & .592 \\
\hline Barnacle cyprids & $\begin{array}{l}\text { Mar } \\
\text { Apr }\end{array}$ & $\begin{array}{l}1 \\
4\end{array}$ & $\begin{array}{l}1 \\
7\end{array}$ & $\begin{array}{l}1 \\
3\end{array}$ & $\begin{array}{l}6 \\
4\end{array}$ & .036 & .500 & .166 \\
\hline Bivalve veligers & $\begin{array}{l}\text { Mar } \\
\text { Apr }\end{array}$ & $\begin{array}{l}99 \\
91\end{array}$ & $\begin{array}{l}134 \\
145\end{array}$ & $\begin{array}{l}188 \\
147\end{array}$ & $\begin{array}{l}173 \\
158\end{array}$ & .304 & .046 & .696 \\
\hline Ascidian tadpoles & Mar & 2 & 3 & 27 & 3 & $\cdots$ & $\ll .001$ & $\cdots$ \\
\hline
\end{tabular}


160
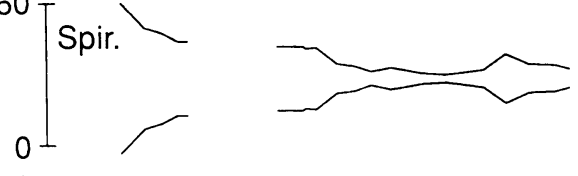

60

Hyd.

$\widehat{N}$

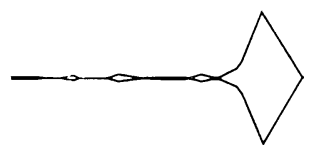

${ }_{\frac{\pi}{0}}^{60}\left[\begin{array}{l}\text { Crep. } \\ =\end{array}\right.$

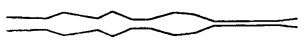

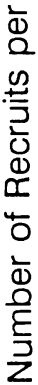

160

Crass.
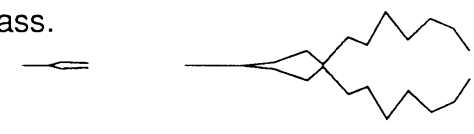

01

1600

Bal.

01
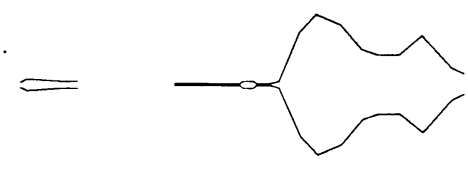

160

Bug.
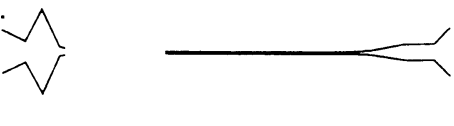

01

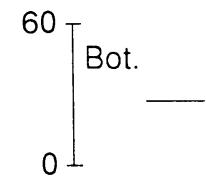

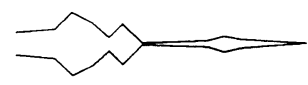

100

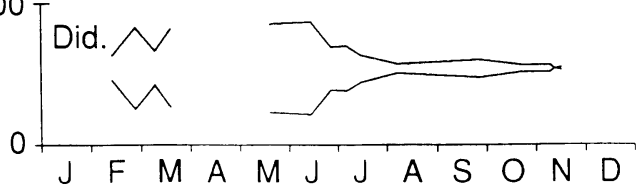

FIG. 8. Recruitment of epifaunal species at Jim Island (Indian River, Florida) from February to November 1987. Recruitment rates are reflected on the $x$ axis, creating "kites" to graphically show recruitment pulses. Values are total daily recruitment on ceramic tiles in 22 channels. Breaks in the recruitment curves are the result of a 2-mo period (1 April1 June) during which no recruitment data were collected. Spir. $=$ Spirorbis sp.; Hyd. $=$ Hydroides sp.; Crep. $=$ Crepidula convexa Crass. $=$ Crassostrea virginica $;$ Bal. $=$ Balanus spp. Bug. $=$ Bugula neritina; Bot. $=$ Botryllus planus; Did. $=$ D $i-$ demnum psammathodes.

\section{DisCuSSION}

The epifaunal communities on Rhizophora mangle roots in Jim Island were extremely diverse, with at least 25 different species common enough to be counted by a point-sampling method. However, as has been reported for many other mangrove habitats, many of these species were patchily distributed. Most striking was the pattern of high species diversity and abundance in the northern channels and lower diversity and much more bare space in the southern channels. The testing of two hypotheses and associated predictions provided insights into the processes that may be responsible for this pattern as well as the distributional patterns for individual species.

\section{Hypothesis 1: physical features structure the community by limiting species' distributions}

The four study channels in Jim Island were quite similar in their physical environments; only flow rate showed statistically significant variability. Obviously, high water flow did not inhibit sessile community development, as the most diverse and abundant epifaunal communities appeared in the High-flow channel (Table 1, Fig. 3). On the other hand, low flow may have been detrimental, as there was little community development on roots in Low-flow channel. Although consistent channel differences were not found in the other physical parameters, measurements revealed that, on occasion, the Low-flow channel also experienced very high turbidity levels; maximum turbidity was 2.8 times that ever measured in the High-flow channel (Table 2). High turbidity and heavy siltation are detrimental to benthic filter-feeding organisms (Moore 1977, Young and Chia 1984), and it is possible that periodically heavy silt loads inhibit growth or survival in the Lowflow channel.

There was little evidence supporting the prediction that mortality would be greater in channels with harsh physical conditions. In most cases, survival and growth of adults transplanted on plates was actually higher in those channels (i.e., Low-flow and High-flow) with more extreme physical features. Results further indicated that individual species' distributions, at least in the short term, were not controlled purely by the physical conditions in a given channel. Several species survived well and showed high growth rates in channels from which they were normally absent (i.e., Botryllus planus in the Grassbed channel, Didemnum psammathodes in the Low-flow channel), and the greatest mortality of D. psammathodes occurred in the Central channel, the very channel where it was normally most abundant (Fig. 3). Although plates and tiles are imperfect mimics for mangrove roots and may have introduced uncontrollable artifacts, there is strong evidence that the absence of species from some channels is not completely due to their inability to survive there.

Surprisingly, early juvenile mortality was near zero for most of the species examined in this study. Unfortunately it was not possible to measure true postsettlement mortality (sensu Keough and Downes 1982), as larvae could have settled anytime during the $5 \mathrm{~d}$ between initial deployment and transplant of the tiles, and it is impossible to conclude absolutely that differential mortality of juveniles $<5 \mathrm{~d}$ old does not con- 
TABLE 4. Recruitment of epifaunal species on ceramic tiles in the four Jim Island study channels, Indian River, Florida. One tile was placed in each of the study channels each sampling period (periods ranged from 10 to $15 \mathrm{~d} ; N=$ number of periods analyzed). Values are means $\pm 1 \mathrm{SD}$ of the number of individuals per tile averaged for all periods in which the species recruited to the tiles.

\begin{tabular}{|c|c|c|c|c|c|}
\hline & Grassbed & Central & Low-flow & High-flow & $N$ \\
\hline \multicolumn{6}{|l|}{ Planktotrophic larvae } \\
\hline $\begin{array}{l}\text { Crassostrea virginica } \\
\text { Balanus spp. }\end{array}$ & $\begin{array}{c}19.8 \pm 24.4 \\
351.8 \pm 466.0\end{array}$ & $\begin{aligned} 21.2 & \pm 32.1 \\
107.6 & \pm 158.0\end{aligned}$ & $\begin{array}{l}11.6 \pm 14.7 \\
54.2 \pm 113.8\end{array}$ & $\begin{array}{c}12.7 \pm 23.9 \\
278.6 \pm 510.2\end{array}$ & $\begin{array}{l}18 \\
18\end{array}$ \\
\hline \multicolumn{6}{|l|}{ Brooded larvae } \\
\hline Crepidula convexa & $6.3 \pm 9.3$ & $6.8 \pm 7.9$ & $0.5 \pm 0.7$ & $0.8 \pm 1.2$ & 18 \\
\hline \multicolumn{6}{|l|}{ Lecithotrophic larvae } \\
\hline Spirorbis sp. & $37.7 \pm 58.9$ & $23.2 \pm 30.9$ & $16.2 \pm 16.6$ & $5.0 \pm 6.3$ & 18 \\
\hline Hydroides sp. & $12.7 \pm 29.7$ & $9.8 \pm 18.9$ & $2.1 \pm 4.1$ & $3.4 \pm 10.8$ & 14 \\
\hline Bugula neritina & $6.7 \pm 8.0$ & $24.7 \pm 25.3$ & $3.6 \pm 2.7$ & $4.5 \pm 6.0$ & 13 \\
\hline Bugula stolonifera & $0.1 \pm 0.2$ & $3.0 \pm 0.9$ & $0.2 \pm 0.4$ & $0.0 \pm \cdots$ & 12 \\
\hline Botryllus planus & $1.4 \pm 1.8$ & $8.6 \pm 15.4$ & $0.7 \pm 2.3$ & $2.5 \pm 4.4$ & 13 \\
\hline Didemnum psammathodes & $4.2 \pm 6.9$ & $17.8 \pm 28.1$ & $3.1 \pm 6.3$ & $4.8 \pm 6.0$ & 17 \\
\hline Symplegma viride & $0.3 \pm 0.9$ & $7.7 \pm 7.7$ & $0.3 \pm 0.7$ & $2.1 \pm 1.7$ & 9 \\
\hline Ascidia nigra & $0.2 \pm 0.4$ & $3.0 \pm 1.5$ & $0.2 \pm 0.4$ & $0.5 \pm 0.4$ & 4 \\
\hline
\end{tabular}

tribute to patterns of abundance. However, juvenile mortalty was generally very low and not concentrated in channels with little epifaunal cover. The only exception was Balanus spp., which showed reduced survival in High- and Low-flow channels (Fig. 5). The source of the mortality that began to occur $5 \mathrm{~d}$ after transplant is unknown. Surviving barnacles were no smaller than those elsewhere, indicating that low growth due to extreme flow or turbidity was not responsible. Perhaps some unmeasured biological factor (e.g., predation) produced this pattern.

In the Indian River the effects of physical parameters on epifaunal organisms are probably important over areas larger than those covered by Jim Island. For example, Mook (1980) found that the diversity of fouling organisms decreased from Fort Pierce Inlet (near Jim Island) to Vero Beach (16 km further up the Indian River), and attributed the pattern to increasing variability in physical features as one moved from the open ocean up the river. Over scales examined in this study (i.e., among channels), however, other factors must be invoked to explain distributions. Physical parameters alone were insufficiently variable to produce observed channel differences in epifaunal cover.

\section{Hypothesis 2: larval supply, as influenced by life history, structures the community}

Larval supply had an important influence on adult distributions at Jim Island. The most obvious effect was that sites on the downstream part of the island received pools of larvae qualitatively and quantitatively different from channels on the upstream side. As a result, root communities in the south side of the island were similar to one another and different from those in the north side.

Grassbed and Low-flow channels (both upstream channels) had large amounts of bare space, few species, and no unique species. Flow reaching both was from extensive seagrass beds to the south. Species reaching these channels, therefore, arrived as short-lived larvae of species present in the seagrass beds, or as long-lived larvae transported in from distant areas. Species not present in the seagrass beds that dispersed by means of short-lived lecithotrophic larvae (e.g., colonial ascidians) were, therefore, underrepresented despite good adult survival.

Because the Central and High-flow channels drained areas of the island with established populations of species with short-lived larvae, both had more epifaunal species, including some unique to those channels ( Table 1), and larger populations of those species (Fig. 3). The Central channel was particularly good for recruit-

TABLE 5. Randomized-block analysis of recruitment in Jim Island study channels (Indian River, Florida). Sampling period was used as a blocking factor and is not included in the table.

\begin{tabular}{|c|c|c|c|}
\hline Species & $F$ & $P$ & Channels* \\
\hline Crassostrea virginica & 2.04 & 0.121 & \\
\hline Balanus spp. & 7.50 & 0.000 & $\underline{\mathrm{GHC}} \mathrm{L}$ \\
\hline Crepidula convexa & 9.49 & 0.000 & $\underline{\mathrm{C}} \underline{\mathrm{H} \mathrm{L}}$ \\
\hline Spirorbis sp. & 4.69 & 0.006 & $\mathrm{GC} \overline{\mathrm{LH}}$ \\
\hline Hydroides sp. & 3.73 & 0.018 & $\underline{\mathrm{C} \mathrm{G} \mathrm{L} \mathrm{H}}$ \\
\hline Bugula neritina & 7.32 & 0.000 & $\underline{\mathrm{C}} \underline{\mathrm{G} \mathrm{L} \mathrm{H}}$ \\
\hline Bugula stolonifera & 7.19 & 0.001 & $\underline{\mathrm{C}} \underline{\mathrm{L} \mathrm{G} \mathrm{H}}$ \\
\hline Ascidia nigra & 9.82 & 0.002 & $\underline{\mathrm{CH}} \mathrm{LG}$ \\
\hline Botryllus planus & 3.17 & 0.031 & 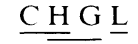 \\
\hline Didemnum psammathodes & 6.27 & 0.001 & C H G L \\
\hline Symplegma viride & 8.16 & 0.000 & $\underline{\mathrm{C}} \underline{\mathrm{H} \mathrm{L} \mathrm{G}}$ \\
\hline
\end{tabular}

${ }^{*} \mathrm{G}=$ Grassbed channel, $\mathrm{C}=$ Central channel, $\mathrm{L}=$ Low flow channel, $\mathrm{H}=\mathrm{High}-$ flow channel. For each species, channels are arranged by decreasing mean recruitment abundance, and underlines connect channels not significantly different by Spjøtvoll and Stoline's a posteriori pairwise comparisons. 
ment of short-lived larvae; most species with lecithotrophic larval development settled in greatest abundance in this channel (Tables 4 and 5). The consistently heavy recruitment of species with larval periods from minutes to hours may have resulted from larval retention; drift tubes revealed that a larva released in the Central channel could remain there for at least $72 \mathrm{~h}-$ much longer than the planktonic periods of most of these lecithotrophic species (Svane and Young 1989, B. L. Bingham, personal observation). This may also explain why the High-flow channel, which presumably received comparable larval pools (as it was on the downstream side of Central channel), did not show greater levels of recruitment even though adults of those species were abundant. Given the high flow rates (Fig. 4) and low retention times (Fig. 7), larvae may simply have been advected from the channel before locating and settling on an appropriate surface.

The prediction that larval life history would influence patterns of supply was supported by plankton sampling. Of five larval forms analyzed, only ascidian tadpoles showed significant variation among channels (maximum abundance in the Central channel where adults were abundant and retention was high, Table 3). Such patchy distribution might be expected, given the very short planktonic periods of these larvae (Berrill 1935, Svane and Young 1989). Longer planktonic periods and increased mixing in water masses may have eliminated patchiness of the other larvae, all of which were long-lived planktotrophs.

Recruitment patterns provided further insights into the importance of larval supply on adult distribution. Recruiting species can be divided into three major groups based on mode of reproduction.

Species with long-lived planktotrophic larvae.-Oyster (Crassostrea virginica) and barnacle (Balanus spp.) populations were evenly distributed within Jim Island (Fig. 3). Because larvae of these species may be in the plankton for weeks, it is unknown where source populations for the Jim Island recruits were located, but it is likely that they were patchily distributed (i.e., on mangrove islands, bridge pilings, and docks). However, given their extended planktonic periods it was expected that larvae would be well mixed in the water masses and that equal recruitment would maintain homogenous adult distributions. This may be the case for $C$. virginica (Tables 4 and 5; Appendix), but recruitment of Balanus spp. was unequal in the study channels. It is unclear what produced its mixed recruitment pattern (highest numbers in channels scattered throughout the island, particularly in the low-flow-type channels; see the Appendix). It is possible that availability of open space was important; with little else settling in the lowflow-type channels more space was available for barnacle recruitment (up to 2850 barnacles settled on a single $15 \times 15 \mathrm{~cm}$ tile in a 10 -d period). Patterns produced by recruitment, however, did not persist in adult populations, and adult and juvenile processes (e.g., competition, predation) and differential mortality (Fig. 5) must be important in equalizing Balanus spp. distributions.

Species that brood. -Crepidula convexa recruitment on tiles was unexpected given its life history. Unlike most Crepidula species, which produce larvae that spend many days in the plankton (Pechenik and Lima 1984), C. convexa undergoes direct development within a brooded egg capsule. Juveniles $(\approx 1 \mathrm{~mm}$ long) released from the capsule swim rarely (Hoagland 1984) or not at all (Hendler and Franz 1971, Lima and Lutz 1990). Although brooded development is generally presumed to preclude planktonic dispersal, considerable movement of this species took place in Jim Island. Juveniles consistently reached tiles not in contact with any surface, presumably through currents that suspended and transported the tiny juveniles. No analysis of adult distributions in the study channels was done, but, as would be predicted based on larval supply and flow patterns, recruitment was highest in channels near the seagrass beds where the adult populations were concentrated (Table 5, Appendix).

Species with short-lived lecithotrophic larvae. - The polychaetes Spirorbis sp. and Hydroides sp. occurred primarily as epifauna on seagrass blades or mollusk shells in the seagrass beds, but both recruited readily into the mangrove habitat. Adults were not common on the roots despite heavy recruitment (Fig. 8) and high early juvenile survival, possibly due to exclusion by other epifauna (Jackson 1977, 1983). Recruitment patterns supported the prediction that recruitment patchiness would correlate with larval life-span. Species in the genus Spirorbis generally release late-stage lecithotrophic larvae which may spend only $15 \mathrm{~min}$ to $2 \mathrm{~h}$ in a completely planktonic phase (Knight-Jones 1951, 1953), while Hydroides species larvae typically spend from 3 to $8 \mathrm{~d}$ in the plankton (Miura and Kajihara 1984). Spirorbis sp. recruits showed significant variability, with proximity to the source populations showing a distinct influence. These effects were much less obvious with Hydroides sp. (Tables 4 and 5).

The bryozoan Zoobotryon verticillatum did not recruit during the study and it appeared that asexual fragmentation and drifting rather than larval dispersal and settlement were responsible for its distributions (Fig. 3). Colonies were significantly more abundant in the High-flow channel than in the other channels despite high survival of transplants everywhere. Because High-flow was the major drainage channel of the island, floating fragments from established Zoobotryon colonies in upstream channels accumulated there. For this bryozoan species, distributions were controlled by dispersal, but dispersal was not dependent on the production of larvae.

The three remaining species that showed significantly patchy adult distributions were colonial ascidians that produce lecithotrophic larvae with limited dispersal potential (Fig. 3). Adults were generally com- 
mon in channels where recruitment was high (i.e., Highflow and Central) and rare in Low-flow and Grassbed channels despite significantly greater growth of transplants there. All of the remaining species that recruited in the island were bryozoans and ascidians that reproduce by means of short-lived larvae. Most of these recruited most heavily in Central and High-flow channels (and other channels of those types, see the Appendix), and distributions of adults corresponded closely with those patterns (Table 1, Fig. 3). Significantly, all eight species that were unique to a given channel produced lecithotrophic larvae.

\section{Conclusions}

Distributions of Rhizophora root epifauna in Jim Island are controlled by a combination of physical and biological factors. Of overwhelming importance is the influence of water flow on import of larvae into the habitat. Effects are especially pronounced for species with short-lived lecithotrophic larvae. Larval supply is patchy, so recruitment patterns and subsequent adult distributions reflect the location of source populations and local patterns of flow. Species producing long-lived planktotrophic larvae are more homogeneously distributed, as larval supply is evened by mixing of water masses during the extended planktonic period. Perhaps the epifaunal patchiness seen in many mangrove epifaunal communities is largely a result of the importance of lecithotrophic species (e.g., sponges, bryozoans, ascidians) in these habitats.

With the exception of the barnacles in Jim Island, post-settlement processes (i.e., differential growth or mortality) did little to modify patterns of distribution evidently created by recruitment. Despite the evidence for larval control of distributions, however, the importance of physical features over longer time scales or larger spatial scales cannot be overlooked. Over many generations, even extremely limited dispersal would eventually result in homogeneous adult distributions. That this has not happened in Jim Island may indicate that recruits sufficient to establish viable populations have not been carried into some channels. Alternatively, other factors may reinforce recruitment patterns and maintain uneven distributions. For example, periodically extreme turbidity may reset the community by killing sensitive sponge, ascidian, and bryozoan species and leaving the more robust barnacles and oysters. Further work is needed to test this possibility.

While it is likely that, on larger scales, physical factors and post-larval processes are important to the $R h i$ zophora root communities, on the scales examined in this study, epifaunal communities in Jim Island are structured primarily by pre-settlement events related to patterns of water flow, proximity to source populations, and length of larval life. Consideration of these features is critical in understanding patterns of epifaunal species' distributions in this unique habitat.

\section{ACKNOWLEDGMENTS}

I gratefully acknowledge field assistance, generally in lessthan-ideal conditions, from the following individuals: C. M. Young, J. L. Cameron, T. Smoyer, A. Davis, J. Dalby, P. Pape, and L. Dilling. C. M. Young, J. L. Cameron, T. Smoyer, N. Smith, D. Hanisak, K. Eckelbarger, D. Simberloff, D. Mariscal, D. Thistle, W. Herrnkind, and A. Ellison commented on various aspects of the work. The owners and staff of the Little Jim Marina were extremely helpful in providing logistical support for this work. This work was supported by Sigma $\mathrm{Xi}$ and NSF grants \#OCE-8400406 and \#OCE-8544845 to C. M. Young. This is Harbor Branch Oceanographic Institution contribution number 913 .

\section{Literature Cited}

Bacon, P. R. 1970. The ecology of Caroni Swamp Trinidad. The Central Statistical Office Printing Unit, Trinidad, West Indies.

Berrill, N. J. 1935. Studies in tunicate development. III. Differential retardation and acceleration. Philosophical Transactions of the Royal Society, Series B 225:255-326.

Bingham, B. L. 1990. The ecology of epifaunal communities on prop roots of the red mangrove, Rhizophora mangle. Dissertation, Florida State University, Tallahassee, Florida, USA.

Davis, C. C., and R. H. Williams. 1950. Brackish water plankton of mangrove areas in southern Florida. Ecology 31:519-531.

Davis, J. H., Jr. 1940. The ecology and geologic role of mangroves in Florida. Papers from Tortugas Laboratory 32:304-424.

Doty, M. S. 1971. Measurement of water movement in reference to benthic algal growth. Botanica Marina 14:3235 .

Ellison, A. M., and E. J. Farnsworth. In press. The ecology of Belizean mangrove-root fouling communities II. Patterns of epibiont distribution and abundance, and effects on root growth. Hydrobiologia.

Frith, D. W., R. Tantanasiriwong, and O. Bhatia. 1976. Zonation and abundance of macrofauna on a mangrove shore, Phuket Island. Phuket Marine Biology Center Research Bulletin 10:1-37.

Gibbons, J. D. 1976. Nonparametric methods for quantitative analysis. Holt, Rinehart and Winston, New York, New York, USA.

Gill, A. M., and P. B. Tomlinson. 1969. Studies on the growth of red mangroves Rhizophora mangle L. I. Habit and general morphology. Biotropica 1:1-9.

Goodbody, I. 1961. Mass mortality of a marine fauna following tropical rains. Ecology 42:150-155.

Hendler, G., and D. R. Franz. 1971. Population dynamics and life history of Crepidula convexa Say Gastropoda: Prosobranchia in Delaware Bay. Biological Bulletin 141:514526.

Hoagland, K. E. 1984. Use of molecular genetics to distinguish species of the gastropod genus Crepidula Prosobranchia: Calyptraeidae. Malacologia 25:607-628.

Jackson, J. B. C. 1977. Competition on marine hard substrata: the adaptive significance of solitary and colonial strategies. American Naturalist 111:743-767.

-1983. Biological determinants of present and past sessile animal distributions. Pages 39-120 in M. J. S. Tevesz and P. L. McCail, editors. Biotic interactions in recent and fossil benthic communities. Plenum, New York, New York, USA.

Keough, M. J., and B. J. Downes. 1982. Recruitment of marine invertebrates: the role of active larval choices and early mortality. Oecologia (Berlin) 54:348-352.

Kirk, R. E. 1982. Experimental design: procedures for the 
behavioral sciences. Brooks/Cole, Monterey, California, USA

Knight-Jones, E. W. 1951. Gregariousness and some other aspects of the settling behavior of Spirorbis. Journal of the Marine Biological Association of the United Kingdom 30: 201-222.

- 1953. Decreased discrimination during settling after prolonged planktonic life of Spirorbis borealis Serpulidae. Journal of the Marine Biological Association of the United Kingdom 32:337-345.

Kolehmainen, S. 1972. Ecology of sessile and free-living organisms on mangrove roots in Jobos Bay. Pages 141-173 in Aguirre Power Project Environmental Studies Annual Report, Puerto Rico Nuclear Center, Rio Piedras, Puerto Rico.

Kolehmainen, S., T. Morgan, and R. Castro. 1974. Mangrove-root communities in a thermally altered area in Guayanilla Bay, Puerto Rico. Pages 371-390 in J. W. Gibbons and R. R. Sharitz, editors. Thermal ecology. Technical Information Center, U.S. Atomic Energy Commission, Washington, D.C., USA.

Kuenzler, E. J. 1974. Mangrove swamp systems. Pages 346371 in H. T. Odum, B. J. Copeland, and E. A. McMahan, editors. Coastal ecological systems of the United States. The Conservation Foundation, Washington, D.C., USA.

Lima, G. M., and R. A. Lutz. 1990. The relationship of larval shell morphology to mode of development in marine prosobranch gastropods. Journal of the Marine Biological Association of the United Kingdom 70:611-637.

Macnae, W. 1963. Mangrove swamps in South Africa. Journal of Ecology 51:1-25.

Macnae, W., and M. Kalk. 1962. The ecology of the mangrove swamps at Inhaca Island, Mozambique. Journal of Ecology 50:19-34.

Miura, T., and T. Kajihara. 1984. An ecological study of the life histories of two Japanese serpulid worms, Hydroides ezoensis and Pomatoleios kraussii. Pages $338-354$ in P. A. Hutchings, editor. Proceedings of the First International Polychaete Conference, Sydney. Linnean Society of New South Wales, New South Wales, Australia.

Mook, D. 1980. Seasonal variation in species composition of recently settled fouling communities along an environmental gradient in the Indian River Lagoon, Florida. Estuarine and Coastal Marine Science 11:573-581.

Moore, P. G. 1977. Inorganic particulate suspension in the sea and their effect on marine animals. Oceanography and Marine Biology Annual Review 15:225-363.

Morgan, T. O. 1977. Growth rate, age at sexual maturity, longevity, and seasonality in three West Indian colonial ascidians. Thesis, University of Puerto Rico, Mayaguez, Puerto Rico.

Parsons, T. R., M. Takahashi, and B. Hargrave. 1984. Biological oceanographic processes. Pergamon Press, Oxford, United Kingdom.

Pechenik, J. A., and G. M. Lima. 1984. Relationship between growth, differentiation, and length of larval life for individually reared larvae of the marine gastropod, Crepidula fornicata. Biological Bulletin 166:537-549.

Rice, W. R. 1989. Analyzing tables of statistical tests. Evolution 43:223-225.

Rützler, K. 1969. The mangrove community, aspects of its structure, faunistics and ecology. Pages 515-535 in Lagunas Costeras, Un Simposio. Universidad Nacional Autónoma de México-UNESCO, Mexico City, Mexico.

Sokal, R. R., and F. J. Rohlf. 1981. Biometry. W. F. Freeman, New York, New York, USA.

Stephenson, T. A., A. Stephenson, G. Tandy, and M. Spender. 1931. The structure and ecology of Low Isles and the other reefs. Scientific Reports of the Great Barrier Reef Expedition 1928-29 3:17-112.

Sutherland, J. P. 1980. Dynamics of the epibenthic community on roots of the mangrove Rhizophora mangle, at Bahía de Buche, Venezuela. Marine Biology 58:75-84.

Svane, I., and C. M. Young. 1989. The ecology and behaviour of ascidian larvae. Oceanography and Marine Biology Annual Review 27:45-90.

Teixeira, C., and M. B. Kutner. 1962. Plankton studies in a mangrove environment. I. First assessment of standing stock and principal ecological factors. Boletim do Instituto Oceanografico 12:101-124.

Teixeira, C., J. Tundisi, and M. B. Kutner. 1965. Plankton studies in a mangrove environment. II. The standing stock and some ecological factors. Boletim do Instituto Oceanografico 14: 13-41.

Walsh, G. E. 1967. An ecological study of a Hawaiian mangrove swamp. Pages 420-431 in G. H. Lauff, editor. Estuaries. American Association for the Advancement of Science, Washington, D.C., USA.

Yoshioka, P. M. 1975. Mangrove root communities in Jobos Bay. Pages 50-169 in Aguirre Power Project Environmental Studies Final Report. Puerto Rico Nuclear Center, Rio Piedras, Puerto Rico.

Young, C. M., and F.S. Chia. 1984. Microhabitat-associated variability in survival and growth of subtidal solitary ascidians during the first 21 days after settlement. Marine Biology 81:61-68.

Zar, J. H. 1984. Biostatistical analysis. Prentice-Hall, Englewood Cliffs, New Jersey, USA. 


\section{APPENDIX}

Recruitment of epifaunal species to $15 \times 15 \mathrm{~cm}$ ceramic tiles hung in the channels of Jim Island, Indian River, Florida (means $\pm 1 \mathrm{SD}$ ). One tile was placed in each channel each sampling period (periods ranging from 10 to $15 \mathrm{~d}, N=$ number of

\begin{tabular}{|c|c|c|c|c|c|c|c|c|}
\hline \multirow[b]{3}{*}{ Channel } & \multirow{3}{*}{$\begin{array}{c}\text { Barnacles } \\
\begin{array}{c}\text { Balanus } \\
\text { spp. }\end{array}\end{array}$} & \multirow{3}{*}{$\begin{array}{c}\text { Oysters } \\
\text { Cras- } \\
\text { sostrea } \\
\text { virginica }\end{array}$} & \multirow{3}{*}{$\begin{array}{c}\text { Limpets } \\
\begin{array}{c}\text { Crepidula } \\
\text { convexa }\end{array}\end{array}$} & \multirow{2}{*}{\multicolumn{2}{|c|}{ Polychaetes }} & \multirow{2}{*}{\multicolumn{3}{|c|}{ Bryozoans }} \\
\hline & & & & & & & & \\
\hline & & & & $\begin{array}{l}\text { Spirorbis } \\
\text { sp. }\end{array}$ & $\begin{array}{l}\text { Hydroides } \\
\text { sp. }\end{array}$ & $\begin{array}{l}\text { Bugula } \\
\text { neritina }\end{array}$ & $\begin{array}{c}\text { Bugula } \\
\text { stolonifera }\end{array}$ & $\begin{array}{c}\text { Watersipora } \\
\text { subovoidea }\end{array}$ \\
\hline \multicolumn{9}{|c|}{ CENTRAL-TYPE } \\
\hline $\mathrm{Cl}$ & $\begin{array}{c}59.7 \\
(90.5)\end{array}$ & $\begin{array}{c}35.6 \\
(45.7)\end{array}$ & $\begin{array}{c}4.5 \\
(3.7)\end{array}$ & $\begin{array}{c}45.2 \\
(64.3)\end{array}$ & $\begin{array}{c}10.8 \\
(19.1)\end{array}$ & $\begin{array}{c}19.7 \\
(14.0)\end{array}$ & $\begin{array}{c}1.5 \\
(2.2)\end{array}$ & $\begin{array}{c}2.0 \\
(1.9)\end{array}$ \\
\hline $\mathrm{C} 2$ & $\begin{array}{c}183.5 \\
(219.3)\end{array}$ & $\begin{array}{c}15.7 \\
(26.6)\end{array}$ & $\begin{array}{c}2.2 \\
(3.9)\end{array}$ & $\begin{array}{c}17.7 \\
(20.9)\end{array}$ & $\begin{array}{c}4.5 \\
(9.0)\end{array}$ & $\begin{array}{c}10.4 \\
(18.4)\end{array}$ & $\begin{array}{c}0.4 \\
(0.8)\end{array}$ & $\begin{array}{c}1.0 \\
(1.0)\end{array}$ \\
\hline $\mathrm{C} 3$ & $\begin{array}{c}19.8 \\
(30.1)\end{array}$ & $\begin{array}{c}19.6 \\
(33.3)\end{array}$ & $\begin{array}{c}3.3 \\
(4.4)\end{array}$ & $\begin{array}{c}18.7 \\
(19.8)\end{array}$ & $\begin{array}{c}4.6 \\
(10.8)\end{array}$ & $\begin{array}{c}6.2 \\
(7.5)\end{array}$ & $\begin{array}{c}0.1 \\
(0.2)\end{array}$ & $\begin{array}{c}1.5 \\
(1.6)\end{array}$ \\
\hline \multicolumn{9}{|c|}{ HIGH-FLOW-TYPE } \\
\hline $\mathrm{H} 1$ & $\begin{array}{c}52.1 \\
(78.5)\end{array}$ & $\begin{array}{c}25.9 \\
(44.0)\end{array}$ & $\begin{array}{l}2.8 \\
(5.6)\end{array}$ & $\begin{array}{c}32.8 \\
(38.3)\end{array}$ & $\begin{array}{c}4.8 \\
(6.9)\end{array}$ & $\begin{array}{l}15.0 \\
(12.0)\end{array}$ & $\begin{array}{c}1.7 \\
(2.8)\end{array}$ & $\begin{array}{c}0.9 \\
(1.1)\end{array}$ \\
\hline $\mathrm{H} 2$ & $\begin{array}{c}115.6 \\
(225.8)\end{array}$ & $\begin{array}{c}30.9 \\
(48.2)\end{array}$ & $\begin{array}{c}4.3 \\
(3.8)\end{array}$ & $\begin{array}{c}37.2 \\
(31.7)\end{array}$ & $\begin{array}{c}3.6 \\
(5.8)\end{array}$ & $\begin{array}{c}9.4 \\
(10.3)\end{array}$ & $\begin{array}{c}0.6 \\
(1.1)\end{array}$ & $\begin{array}{c}4.3 \\
(4.0)\end{array}$ \\
\hline $\mathrm{H} 3$ & $\begin{array}{c}196.6 \\
(279.5)\end{array}$ & $\begin{array}{l}16.8 \\
(21.3)\end{array}$ & $\begin{array}{c}0.3 \\
(0.6)\end{array}$ & $\begin{array}{c}14.3 \\
(17.6)\end{array}$ & $\begin{array}{c}3.2 \\
(5.7)\end{array}$ & $\begin{array}{l}19.7 \\
(7.5)\end{array}$ & $\begin{array}{c}0.1 \\
(0.3)\end{array}$ & $\begin{array}{c}0.6 \\
(1.2)\end{array}$ \\
\hline $\mathrm{H} 4$ & $\begin{array}{c}540.3 \\
(599.7)\end{array}$ & $\begin{array}{c}4.8 \\
(7.1)\end{array}$ & $\begin{array}{c}0.2 \\
(0.4)\end{array}$ & $\begin{array}{c}7.2 \\
(11.1)\end{array}$ & $\begin{array}{c}0.5 \\
(1.4)\end{array}$ & $\begin{array}{c}5.1 \\
(5.8)\end{array}$ & $\begin{array}{c}0.1 \\
(0.3)\end{array}$ & $\begin{array}{c}0.2 \\
(0.6)\end{array}$ \\
\hline \multicolumn{9}{|c|}{ GRASSBED-TYPE } \\
\hline G1 & $\begin{array}{c}166.9 \\
(252.0)\end{array}$ & $\begin{array}{c}17.8 \\
(29.6)\end{array}$ & $\begin{array}{c}2.9 \\
(3.4)\end{array}$ & $\begin{array}{c}43.7 \\
(67.4)\end{array}$ & $\begin{array}{c}6.9 \\
(9.9)\end{array}$ & $\begin{array}{c}24.9 \\
(32.5)\end{array}$ & $\begin{array}{c}0.6 \\
(1.2)\end{array}$ & $\begin{array}{c}0.5 \\
(1.1)\end{array}$ \\
\hline G2 & $\begin{array}{c}94.0 \\
(101.7)\end{array}$ & $\begin{array}{c}31.4 \\
(46.5)\end{array}$ & $\begin{array}{c}4.8 \\
(7.5)\end{array}$ & $\begin{array}{c}25.4 \\
(44.9)\end{array}$ & $\begin{array}{c}19.6 \\
(49.8)\end{array}$ & $\begin{array}{c}8.6 \\
(8.8)\end{array}$ & $\begin{array}{c}0.2 \\
(0.8)\end{array}$ & $\begin{array}{c}0.2 \\
(0.4)\end{array}$ \\
\hline G3 & $\begin{array}{c}54.6 \\
(92.9)\end{array}$ & $\begin{array}{c}31.4 \\
(40.6)\end{array}$ & $\begin{array}{l}2.8 \\
(2.3)\end{array}$ & $\begin{array}{c}31.7 \\
(35.9)\end{array}$ & $\begin{array}{c}9.1 \\
(12.5)\end{array}$ & $\begin{array}{l}21 \\
(16.2)\end{array}$ & $\begin{array}{c}0.5 \\
(1.1)\end{array}$ & $\begin{array}{c}1.3 \\
(1.4)\end{array}$ \\
\hline \multicolumn{9}{|c|}{ LOW-FLOW-TYPE } \\
\hline $\mathrm{L} 1$ & $\begin{array}{c}524.0 \\
(723.1)\end{array}$ & $\begin{array}{c}16.9 \\
(24.5)\end{array}$ & $\begin{array}{c}0.6 \\
(0.8)\end{array}$ & $\begin{array}{c}11.1 \\
(18.7)\end{array}$ & $\begin{array}{c}1.9 \\
(2.6)\end{array}$ & $\begin{array}{c}8.8 \\
(10.4)\end{array}$ & $\begin{array}{c}0.1 \\
(0.2)\end{array}$ & $\begin{array}{c}0.2 \\
(0.4)\end{array}$ \\
\hline $\mathrm{L} 2$ & $\begin{array}{c}152.1 \\
(230.3)\end{array}$ & $\begin{array}{c}24.3 \\
(27.9)\end{array}$ & $\begin{array}{c}1.2 \\
(3.2)\end{array}$ & $\begin{array}{c}19.3 \\
(23.4)\end{array}$ & $\begin{array}{c}5.5 \\
(7.2)\end{array}$ & $\begin{array}{c}7.2 \\
(7.0)\end{array}$ & $\begin{array}{c}0.4 \\
(0.5)\end{array}$ & $\begin{array}{c}0.7 \\
(0.8)\end{array}$ \\
\hline L3 & $\begin{array}{c}325.8 \\
(447.1)\end{array}$ & $\begin{array}{c}8.2 \\
(14.5)\end{array}$ & $\begin{array}{c}0.2 \\
(0.4)\end{array}$ & $\begin{array}{l}16.6 \\
(27.2)\end{array}$ & $\begin{array}{c}3.7 \\
(9.1)\end{array}$ & $\begin{array}{c}25.9 \\
(29.1)\end{array}$ & $\begin{array}{c}0.1 \\
(0.5)\end{array}$ & $\begin{array}{c}0.6 \\
(1.1)\end{array}$ \\
\hline L4 & $\begin{array}{c}360.2 \\
(555.7)\end{array}$ & $\begin{array}{c}5.9 \\
(12.3)\end{array}$ & $\begin{array}{c}0.6 \\
(0.8)\end{array}$ & $\begin{array}{c}6.8 \\
(10.4)\end{array}$ & $\begin{array}{c}0.7 \\
(1.6)\end{array}$ & $\begin{array}{c}7.8 \\
(16.8)\end{array}$ & $\begin{array}{c}0.1 \\
(0.5)\end{array}$ & $\begin{array}{c}1.2 \\
(2.7)\end{array}$ \\
\hline L5 & $\begin{array}{c}498.1 \\
(718.2)\end{array}$ & $\begin{array}{c}1.1 \\
(1.4)\end{array}$ & $\begin{array}{c}0.4 \\
(0.9)\end{array}$ & $\begin{array}{c}7.2 \\
(12.5)\end{array}$ & $\begin{array}{c}0.9 \\
(2.5)\end{array}$ & $\begin{array}{c}20.2 \\
(40.2)\end{array}$ & $\begin{array}{c}0.2 \\
(0.4)\end{array}$ & $\begin{array}{c}1.2 \\
(2.3)\end{array}$ \\
\hline L6 & $\begin{array}{c}242.3 \\
(564.9)\end{array}$ & $\begin{array}{c}8.7 \\
(13.1)\end{array}$ & $\begin{array}{c}2.0 \\
(2.5)\end{array}$ & $\begin{array}{c}7.3 \\
(7.6)\end{array}$ & $\begin{array}{c}1.5 \\
(2.4)\end{array}$ & $\begin{array}{c}15.3 \\
(13.1)\end{array}$ & $\begin{array}{c}0.3 \\
(0.6)\end{array}$ & $\begin{array}{c}1.4 \\
(2.1)\end{array}$ \\
\hline $\mathrm{L} 7$ & $\begin{array}{c}348.5 \\
(479.4)\end{array}$ & $\begin{array}{c}11.4 \\
(21.2)\end{array}$ & $\begin{array}{c}0.4 \\
(1.1)\end{array}$ & $\begin{array}{c}3.4 \\
(3.3)\end{array}$ & $\begin{array}{c}2.9 \\
(8.6)\end{array}$ & $\begin{array}{l}1.9 \\
(2.6)\end{array}$ & $\begin{array}{c}0.4 \\
(0.7)\end{array}$ & $\begin{array}{c}1.4 \\
(2.8)\end{array}$ \\
\hline L8 & $\begin{array}{c}609.4 \\
(826.6)\end{array}$ & $\begin{array}{c}3.7 \\
(5.2)\end{array}$ & $\begin{array}{c}0.3 \\
(0.7)\end{array}$ & $\begin{array}{c}5.4 \\
(6.7)\end{array}$ & $\begin{array}{c}0.6 \\
(1.5)\end{array}$ & $\begin{array}{l}22.1 \\
(17.7)\end{array}$ & $\begin{array}{c}1.2 \\
(1.7)\end{array}$ & $\begin{array}{c}0.4 \\
(0.9)\end{array}$ \\
\hline$N$ & 18 & 18 & 18 & 18 & 14 & 9 & 12 & 11 \\
\hline
\end{tabular}


APPENDIX. Continued.

periods analyzed). Channels are grouped into categories with one of the main study channels, based on locations and patterns of water flow through Jim Island.

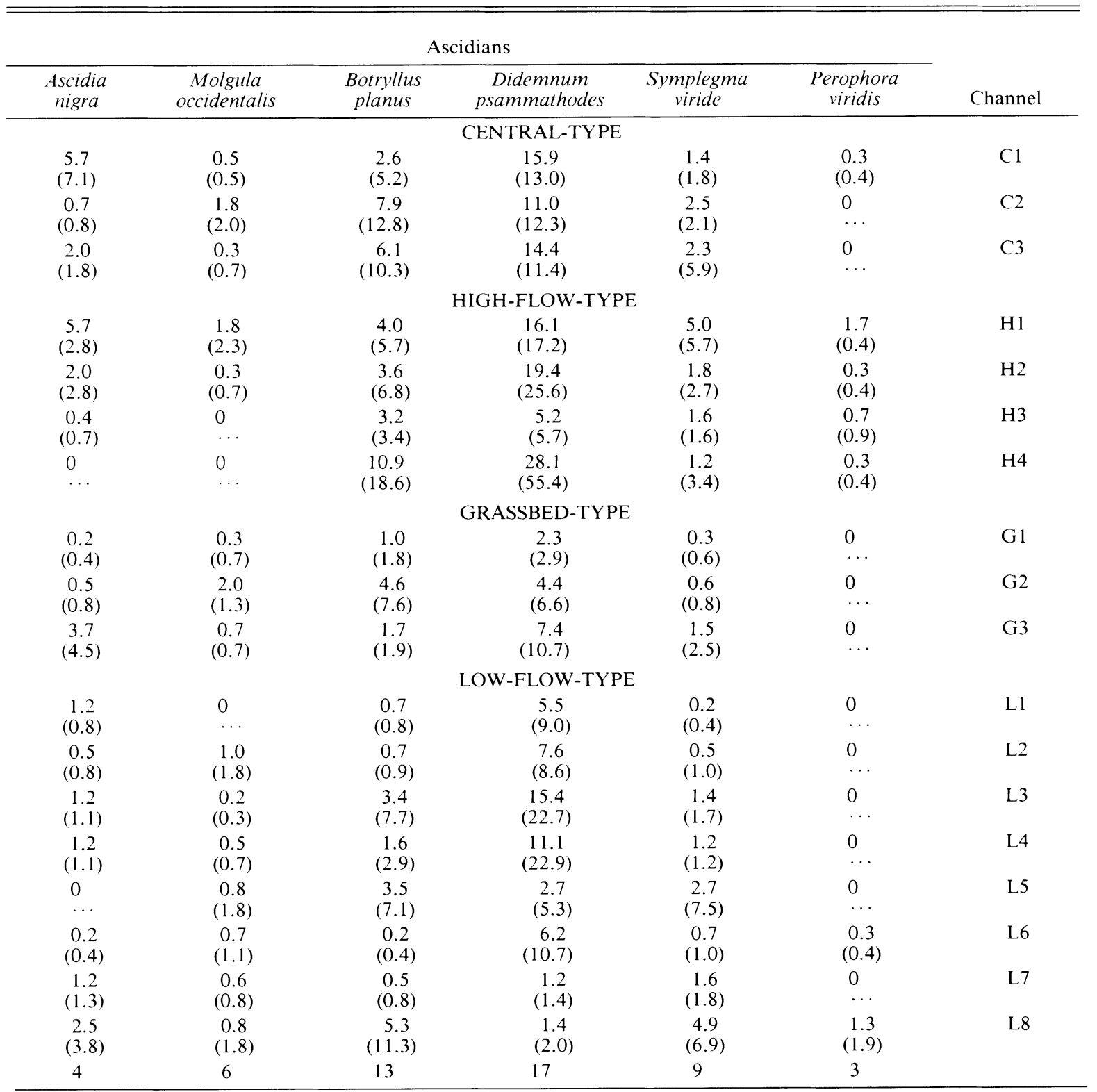

